\title{
STUDENTS' PERCEPTIONS ON THEIR READINESS TO STUDY ONLINE: A CASE STUDY OF ONE UNIVERSITY IN SURABAYA
}

\author{
Zainul Aminin', Ayunita Leliana ${ }^{2}$ \\ ${ }^{1}$ Universitas Negeri Surabaya \\ ${ }^{1}$ zainulaminin@unesa.ac.id, ${ }^{2}$ ayunitaleliana@unesa.ac.id
}

\begin{abstract}
The purpose of this study was to explore students' activities and perceptions in carrying out online lectures through the WhatsApp Group application, Google Classroom, and Zoom and finding effective ways to study during the COVID-19 outbreak. This study was expected to identify the readiness of students to follow online lectures and find effective ways to study as well as being the basis for higher education institutions to establish policies for implementing online lectures. The researcher used a qualitative study. The participants were the 33 EFL students of the English Department both male and female who joined the Essential Writing Class. The researcher used convenience sampling which invited subjects to participate. The instruments used in this research were a questionnaire and a semi-structured interview. Data analysis used was thematic coding. The results show that most students were ready to study online. They only focused on the material. However, they did not pay attention to the way they learned; that was online learning. There are three aspects involved to make the class more effective; they are the lecturer, the students, and the media. These three aspects must work together to create effective online courses.
\end{abstract}

Keywords: Perception, Readiness, Online

\section{INTRODUCTION}

In December 2019, it was reported that a new type of corona virus or SARS-CoV-2 first appeared. The virus that causes respiratory problems has spread to almost all countries in the world. The spread was so fast, 3 months after the first report in Wuhan China, the virus had entered Indonesia. Seeing the spread of the corona virus, the world health organization (WHO) has declared Covid-19 a global pandemic. The Covid-19 pandemic is currently a global health threat with confirmed cases and a fairly high mortality rate (Gt Walker, P. et al., 2020). To stop the spread of the virus, many countries have implemented lockdowns to stop all outgoing and incoming activities. In Indonesia, although it has not fully implemented a lockdown, many regions have implemented Large-Scale Social Restrictions in their respective territories. People are asked to stay at home and reduce activities outside their home.

Limiting ourselves to staying at home for long periods has many consequences. The main goal to break the chain of spreading the corona virus is right on target. However, this has also resulted in various negative impacts, especially on the economic and education sectors in Indonesia. Many losses are suffered by large, medium, and small industries which resulted in layoffs for their employees. In the education sector, teaching and learning activities must be carried out using an online system. Pragholapati (2020) explained that to stop the spread of Covid-19, WHO recommended all activities that could potentially cause mass gathering must be avoided. Therefore, conventional learning, which gathers many students in one class, must be reviewed for its implementation. 
In response to this, Firman (2020) says that many lecturers have finally changed modes of learning. Conventional learning in the classroom becomes online learning that students can follow from anywhere. Online learning is implemented either synchronously or asynchronously using a web service or learning applications. Synchronous learning is carried out through video conferencing. Lecturers and students meet and communicate in real-time using the Zoom app or Google Meet. Meanwhile, asynchronous learning is carried out using applications such as Google Classroom, Edmodo, WhatsApp, and Email. Lecturers upload the lessons such as reading material, instructional videos, or material links available on the web to the learning application used. Students can provide feedback or questions via the chat feature provided or using WhatsApp.

Mulyana et al. (2020) state that for higher education academics who are familiar with online learning, lectures using internet-based information technology will not be a problem. Lectures will run effectively and normally. They only need to increase the portion of online meetings or change face-to-face sessions in class to online meetings on the internet. On the other hand, for higher education institutions and individuals, the lecturers and students who are not familiar with online lectures will experience problems and need adjustments. Adaptations need to be done quickly to run online lectures. Hence, it is necessary to understand students' perceptions of their readiness to study online.

The purpose of this study was to explore students' activities and perceptions in carrying out online lectures through the WhatsApp Group application, Google Classroom, and Zoom and finding effective ways to study during the COVID-19 outbreak. This study was expected to identify the readiness of students to follow online lectures and find effective ways to study as well as being the basis for higher education institutions to establish policies for implementing online lectures.

\section{METHOD}

The researcher used a qualitative study. Heigham and Croker (2009) state that qualitative study includes, in particular, textual evidence and is analyzed using an interpretive analysis. Moreover, Bogdan and Tylor (1990) state that qualitative analysis is a research technique that generates descriptive results, both oral and written, from individuals and actions that can be observed. In this research, the researcher figured out the students' perceptions on their readiness to study online and revealed the effective ways to study during the pandemic.

The participants were 33 EFL students of the English Department, both male and female who joined the Essential Writing Class. All of them were freshmen, the students of 2020. There were 20 female and 13 male students. 


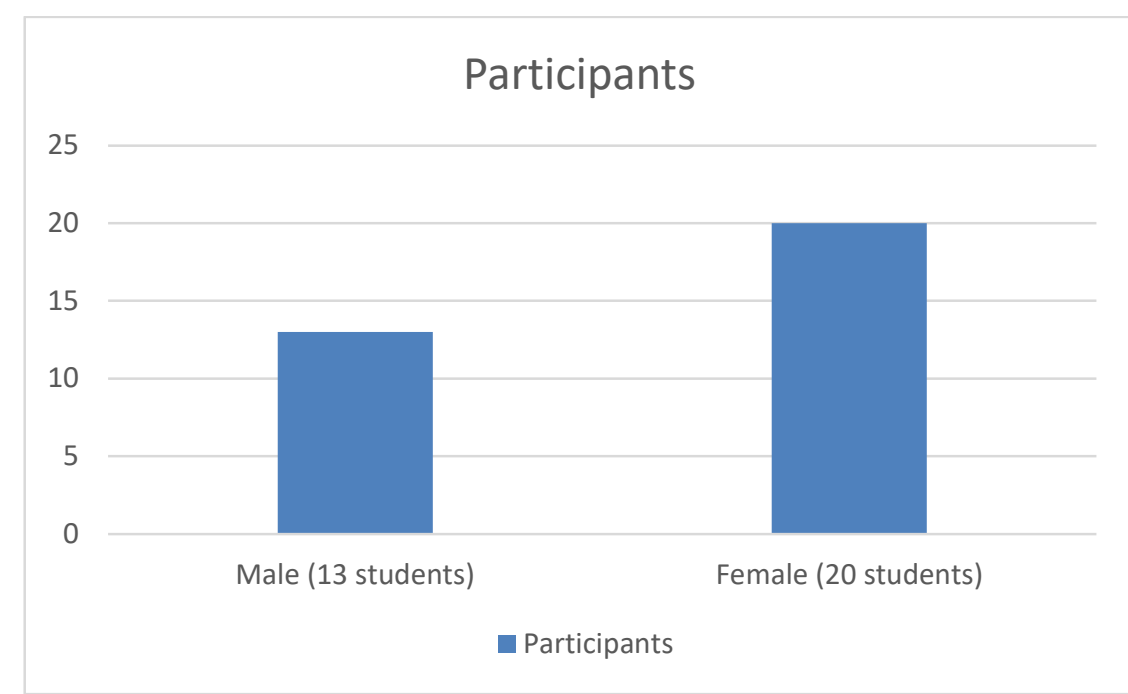

Figure 1 Participants of the study

The researcher used convenience sampling or commonly called availability sampling. A specific kind of non-probability sampling method that focuses on data collection by members of the population who are readily available to participate in the study refers to this kind of sampling. Convenience sampling is a method of sampling where the first available primary data source can be used for testing purposes without additional criteria. In other words, this sampling approach means getting participants anywhere they can be found, and ideally wherever they are accessible. For convenience sampling, no inclusion requirements have been established prior to the selection of subjects. All subjects are encouraged to take part.

The instruments used in this research were an open questionnaire and a semi-structured interview. An open questionnaire is a questionnaire in which respondents are given the freedom to answer and no answer choices are provided. The semi-structured interview is an ongoing interview that refers to a series of open-ended questions. This method allows new questions to emerge because of the answers given by the speakers so that during the session, more in-depth information can be extracted.

Data analysis used was thematic coding. Thematic coding is a type of qualitative research that includes capturing or labeling text passages, or images that are related to a common concept or concept that helps the researcher to index text to categories and hence create a "framework of thematic ideas about it" (Gibbs, 2007). Although there are several different approaches to thematic analysis, each choice is also a form of thematic coding. It is important to interpret the text in a theoretical or logical manner, rather than simply observing it with a descriptive perspective. Intensive reading has to take part during this process to verify that someone is able to find the important concepts in the text.

\section{RESULTS AND DISCUSSION}

\section{Results}

\section{Students' Readiness to Study Online}

Based on the question given to the students, most of them felt prepared for the lesson that day. Thirty-one students said that they were ready to study and only two students said that they were not ready to study. 


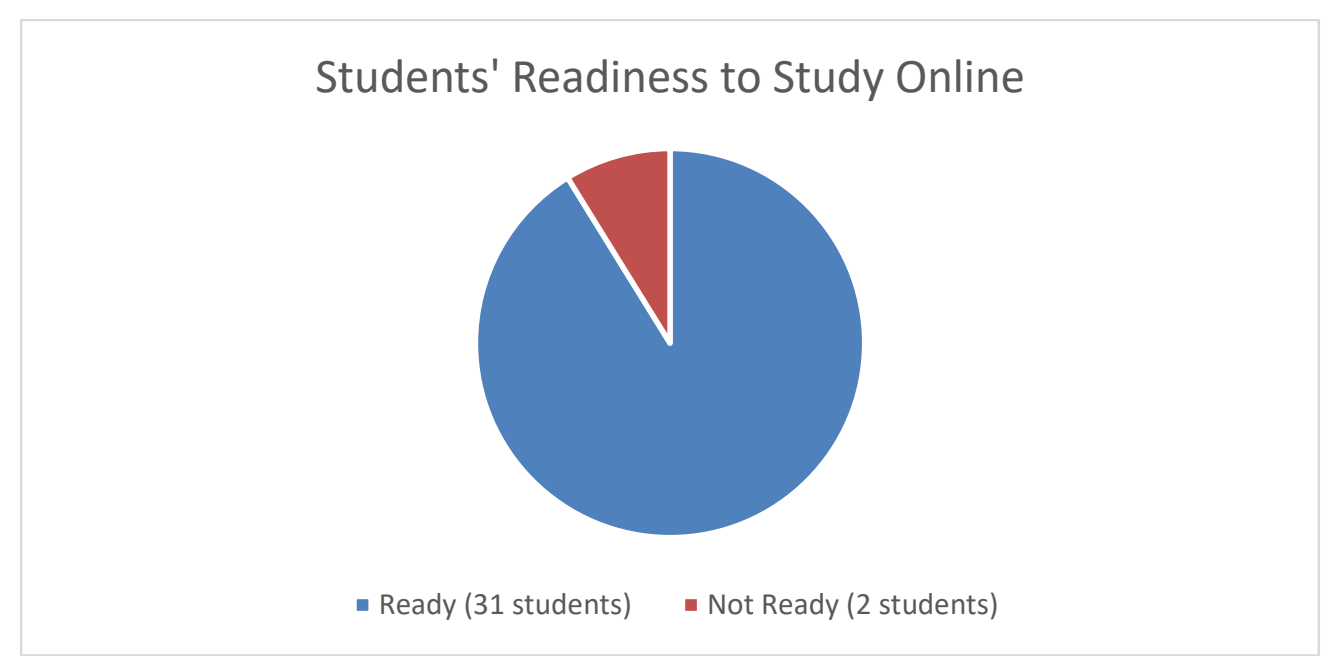

Figure 2 Students' Readiness to Study Online

There were some reasons why the students felt prepared to study that day. The first was they have already read the material from the book provided by the lecturer. They followed the lecturer's instruction to read the book a few days before the class began. Here are some students' responses:

A: Yes, because I have read the material, which the lecturer suggested.

B: Yes, because the lecturer has already given the materials in the group.

So it is easy to understand the materials while studying.

C: Yes I did, because I have already studied this lesson last night.

D: I felt prepared for today's lesson, because I've read the source that I needed for today's lesson.

The second reason was the students have made their own summary or note. After reading the book, they took some notes about the important points of the material. Here are the students' answers:

A: Yes, I have. Since last night, I have prepared the material for today. I have took a note from the e-book, so that if the lecture give the explanation about the material, I can pay attention clearly.

B: Yes, I did. Because last night I read, the book and I made my own summary.

The third was the students understood the lesson but they did not have self-confident to speak because they felt that their speaking skill was not good enough. Here are some students' answers:

A: Yes, but I still doubt to ask, because I am still confused to speak English.

B: I think that I feel prepared for today's lesson but I cannot give my opinion because I feel bad for speaking but in the next meeting, I will try my best.

The forth was the students liked the topic/material. They thought that they understood the material well. Here is the student's response:

A: Yes, I did. Because I like today's topic / material which I can understand very well. From the meaning of the paragraph to the important point of topic sentence so that I can distinguish the correct use of words in making sentences.

The last was the students were excited to learn English. They were freshmen. They had high motivation to learn. It was the first time for joining the class. Here is the student's answer: 
A: yes, because I am really excited to learn about English.

Two students responded they were not ready for the class. They did not feel prepared for the lesson because they did not understand the material even though they have read it. They needed to read more to answer the questions related to the topic discussed. Here are some students' responses:

A: Not really because I think I need to read more to answer correctly.

B: Not really because I only read the book last night but I don't really understand, glad the lecturer explained it so well.

\section{How to make the lesson more effective}

In order to make the class more effective, the students proposed some suggestions based on the interview. First, most students said that the class was already effective because the lecturer explained the material clearly and the explanation was easy to understand. The lecturer also gave the opportunity to ask some questions and speak up about their opinion freely. Here are the students' suggestions:

A: It's already effective because we were given a chance to speak in the class by the lecturer, even though it's still awkward for me. I'm sorry, sir.

B: Overall it's good.

$\mathrm{C}$ : It is because the lecturer is accurate for answering the question and easy to understand and provide material in detail.

D: The lecturer lets the students speak up about their own opinion freely.

E: I think this is effective, but because done by daring sometimes I am confused But, I thank you so much for your knowledge, I hope you always be the best teacher. And I'm so sorry for my mistake.

F: Question, it's like when lecturer has done explained a lesson, he asked the students about question that concerns to that lesson and also he asked the students whether they have any questions about the lesson or no.

G: What made today's lesson more effective was the lecturer's explanation that was easy to understand and he didn't speak too fast.

Second, the class could be more effective if the students take notes and do the assignments. Doing the assignments would make the students practice a lot. Here are the students' answers:

A: Taking notes and doing the assignment.

B: More practice of writing paragraph.

C: Doing the assignment.

D: The lecturer explains the material clearly. So, I can understand and I can make a note from that material.

E: The explanation from the lecturer has really helped me in today's learning, how to explain the lecturer which made me understand the material discussed earlier. Then for the next, I will try to practice making the correct topic sentence in paragraphs.

F: Practice of writing a paragraph and analysing.

Third, the class was more effective if the students had stable internet connection and signal. Some students could not join the class well because they experienced unstable internet connection. They could not attend completely. Here are the students' responses:

A: I think the class can effective depend on the connecting and signal.

$\mathrm{B}$ : The link of lesson was given on time and easy to access. 
C: I think the lesson more effective if we have a good situation around us and good internet connection.

D: Smooth network.

E: From my honest opinion, it's already effective. The problem is just from my own network which sometimes get error/lag so I can't hear clearly what materials the lecturer explain about. However, the rest is good enough.

Fourth, the class would be more effective if there was more interaction/discussion between the lecturer and the students. The students expected the lecturer gave more examples so that they had better understanding. Here are some students' answers:

A: Maybe more interaction between students and lectures... And more example of the topic we discuss.

B: Today's lesson is already effective, but I think we have to be more active in today's class to make it more interesting.

C: I will help make today's lesson more effective is to be active when discussing like this was done on Google Meet.

D: I think when the lecture was giving the chance to answer his question. So, we can think and answer logically to the question. In addition, the lecture also gave the correction if we were wrong, so it makes me understand from that.

E: I think all the participant must be more active so we can exchange more opinion.

Fifth, the class could be more effective if it was conducted offline. There was one student who suggested an offline class. It could be he was not comfortable with the online class. Here is his response:

A: offline class

\section{Discussion}

Most students said that they felt prepared for the lesson that day. Only a few of them said that they were not ready. There are several reasons that make them ready to study. First, the students have already read the material from the book provided by the lecturer. Second, they have made their own summary or note. Third, the students understood the lesson but they did not have the self-confidence to speak. Fourth, they liked the topic/material. Fifth, the students were excited to learn English.

Based on the students' responses, they only focused on the material that would be delivered by the lecturer. They did not pay attention to the way they learned; that was online learning, while it is important to prepare all the things related to online courses, such as computer or laptop, internet connection, application software, etc. As Firman (2020) says students are also required to be able to take advantage of existing devices they have for learning. If all this time they use smartphones only for communication and entertainment purposes, during the Covid-19 pandemic students should be able to use their smartphones for their purposes of learning. They also must be able to use their smartphones to take virtual classes, which can be accessed through online learning applications. According to Herrington, A., \& Herrington, J. (2007) the use of mobile technology in universities has increased. El-Hussein, M. O. M., \& Cronje, J. C. (2010) states that nowadays, devices have connectivity that supports access to materials that are available on the web so that many students especially in developing countries use it as a support tool for online learning. 
There are some ways to make the class more effective. First, the lecturer explains the material clearly and give the opportunity to ask some questions and speak up freely. Second, students take notes and do the assignments. Third, the students have stable internet connection and signal. Fourth, there is more interaction/discussion between the lecture and the students. Fifth, the class is done offline.

In brief, there are three aspects involved to make the class more effective; they are the lecturer, the students, and the media. Examples of media for online learning are laptops, smartphones, applications (Zoom, Google Meet, WhatsApp, Google Classroom, Edmodo, etc.), internet connection, etc. Firman (2020) says that the implementation of online learning during the Covid-19 pandemic changed the whole learning process. To prevent the spread of Covid-19 on campus, academic activities on the campus are stopped. The lecturers carry out online learning so that students can still follow lectures online from their respective homes. As Ismail, Almekhlafi, and Almekhlafy (2010) have pointed out the irresistible impact of technology will stimulate the learning process of students and teachers to incorporate technology into classrooms. In addition, Viatonu and Kayode (2012) suggest that teachers and learners need to be familiar with the convergence of information and communication technology available for teaching English.

\section{CONCLUSION}

Most students were ready to study online. They have already read the material from the book provided by the lecturer and taken notes. They only focused on the material. However, they did not pay attention to the way they learned; that was online learning. They needed to prepare all the things related to online courses, such as computer or laptop, internet connection, application software, etc. They must be able to use their devices and technology to take virtual classes.

There are some ways to make the class more effective. The lecturer explains the material clearly. Students take notes and do the assignments. The lecturer and students have stable internet connection. Three aspects are involved to make the class more effective; they are the lecturer, the students, and the media. These three aspects must work together in order to create effective online courses.

\section{ACKNOWLEDGMENTS}

This is an independent-funding research.

\section{REFERENCES}

El-Hussein, M. O. M., \& Cronje, J. C. (2010). Defining mobile learning in the higher education landscape. Journal of Educational Technology \& Society, 13(3), 12-21.

Firman, F. (2020). Dampak Covid-19 terhadap Pembelajaran di Perguruan Tinggi. BIOMA: Jurnal Biologi dan Pembelajarannya, 2(1), 14-20.

Gibbs, G. R. (2007). Thematic coding and categorizing. Analyzing qualitative data, 703, 3856.

Heigham, J., \& Croker, R. (Eds.). (2009). Qualitative research in applied linguistics: A practical introduction. Springer.

Herrington, A., \& Herrington, J. (2007). Authentic mobile learning in higher education. 
Ismail, S., Almekhlafi, A. G., \& Al-Mekhlafy, M. H. (2010). Teachers' perceptions of the use of technology in teaching languages in United Arab Emirates' schools. International Journal for Research in Education, 27(1), 37-56.

Mulyana, M., Rainanto, B. H., Astrini, D., \& Puspitasari, R. (2020). Persepsi Mahasiswa Atas Penggunaan Aplikasi Perkuliahan Daring Saat Wabah Covid-19. JAS-PT (Jurnal Analisis Sistem Pendidikan Tinggi Indonesia), 4(1), 47-56.

Pragholapati, A. (2020). COVID-19 impact on students.

Viatonu, O., \& Kayode, E. T. (2012). Improving the teaching and learning of English language through the use of information and communication technology: prospects and challenges. In International Conference "ICT for Language Learning".

Walker, P. G., Whittaker, C., Watson, O. J., Baguelin, M., Winskill, P., Hamlet, A., ... \& Ghani, A. C. (2020). The impact of COVID-19 and strategies for mitigation and suppression in low-and middle-income countries. Science, 369(6502), 413-422. 